\title{
Built Environment Professionals' Perceptions of the Effectiveness of Building Control Measures in Lagos State
}

\author{
*Rapheal Abiodun Ojelabi', Opeyemi Olanrewaju Oyeyipo² and \\ Adedeji Afolabil
}

Published online: 30 August 2017

To cite this article: Rapheal Abiodun Ojelabi, Opeyemi Olanrewaju Oyeyipo and Adedeji Afolabi. (2017). Built environment professionals' perceptions of the effectiveness of building control measures in Lagos state. Journal of Construction in Developing Countries, 22(1): 41-54. https://doi.org/10.21315/jcdc2017.22.1.3

To link to this article: https://doi.org/10.21315/jcdc2017.22.1.3

Abstract: Due to the alarming rate of building collapse, this study assesses building control practices in Lagos state. It examines the effectiveness of building control practices, and it also identifies the factors limiting the capacity of building control practices. To achieve these objectives, quantitative techniques were used in which 61 questionnaires were distributed to selected professionals from contracting firms within the built environment. The sample was selected using the purposive sampling technique. The data collected were processed using mean item score, percentage and ANOVA. The study revealed that not all building control measures were thoroughly observed. It was discovered from the findings that, aside from the measure of processing and scrutinising the building plans for approval, which was duly observed, no other measures were observed, and they are all equally significant. The study also identifies factors that impede adherence to building control practices, such as corruption and the bureaucratic process, which were ranked highest. Hypothesis testing revealed that there is no significant difference among the professionals in their perception of the effectiveness of building control practices. In conclusion, this study recommends regular auditing of the activities of building control agencies due to the prevalence of corruption cases among their members.

Keywords: Building control, Sustainability, Lagos state, Built environment, Building construction

\section{INTRODUCTION}

Lagos state, without a doubt, is one of the developing cities in Africa. Filani (2012) affirmed that Lagos is the economic bedrock of Nigeria and the sub-region of West Africa, as it yields 32 percent of the national gross domestic product (GDP). Osinbajo (2004) cited in his paper, Problem and Prospect of Development Control, that Lagos was expected to join the league of mega cities by 2015 , with the World Bank projecting a population of 24.5 million. However, irrespective of the projected population of Lagos, there have not been corresponding plans for the provision of social amenities that will accommodate the increasing population. Attempts by individual inhabitants of the state to meet their housing needs have led to personal development of housing, in which building regulations are not given top priority. Disregard of building regulations has culminated in various challenges, such as an incessant rate of building collapse, building fires, and land pollution, in our built environment. To curtail the challenges confronting the built

'Department of Building, Covenant University, Ota Ogun, NIGERIA

2Department of Quantity Surveying, Bells University of Technology, Ota Ogun, NIGERIA

"Corresponding author: rapheal.ojelabi@covenantuniversity.edu.ng

(C) Penerbit Universiti Sains Malaysia, 2017. This work is licensed under the terms of the Creative Commons Attribution (CC BY) (http://creativecommons.org/licenses/by/4.0/). 
environment, there is a need to control building construction. Control and order are of necessity, as these two factors define the sustainability of our environment. As cited by Hossein, Farah and Leila (2012), the built environment is a key player in promoting sustainable development to preserve quality of life, comfort, security and health, among others; these goals can only be achieved under a controlled environment.

Moreover, any developments that do not consider health, welfare and quality of life should be discouraged. Therefore, it is necessary to control building construction activities. Building control is aimed at ensuring the health and safety of building users and facilitating sustainable development. According to Pedro, Meijer and Visscher (2009), building control is an indispensable tool that ensures the application of the minimum requirements set for building construction to guarantee safe, healthy and accessible buildings. Alexander (2011) affirmed that the building control system is meant to regulate building design to ensure safe, healthy, accessible and sustainable building facilities for current and future generations. However, the safety and sustainability of our built environment can be questioned due to various reports on the performance of our built structures and the use of our land-based resources. The use of our buildings and the activities that created them do not consider the sustainable principle of safety for the present and future generations. Additionally, the abuse of our landed resources is evidenced in the activities that are carried out on them, and as such, it could deny the generation to come of this monumental wealth.

The preservation of our built environment is not an option; it is necessary for humankind's existence. Pedro et al. (2009) revealed that developed nations are comfortable with the relevance of the building control system, and it is a tool that is used to ensure the sustainability of their built environments. Similarly, Van der Heijden and De Jong (2013) cited the importance of building regulations and their enforcement in the developed world in overhauling unhealthy practices that have caused poor housing conditions and unhealthy environments in their built environments in past years. However, it is different in our society, as we experience the mismanagement of our land, recurring periods of building collapse, building fires, sick buildings, and urban defacement. As such, in 2010, the Lagos state government established a building control agency to control building construction activities within the state. Creating a system to respond to some needs within the environment also demands the consistently assessment of its adequacy. As such, it is pertinent for this study to carry out organised inquiries into the effectiveness of the building control system in Lagos state. This paper focuses on the measures of enforcement of building regulations within the built environment with the use of building control tools. The study is aimed at examining the professionals' perceptions of the effectiveness of building control as an enforcement tool in achieving building regulation standards and also identifying factors confronting the implementation of building control practices. The study also hypothesises that there are no significant differences among the professionals in their perception of the measures of enforcement of building control. 


\section{LITERATURE REVIEW}

Building construction is essential for the development of every nation around the world. It contributes to the measure of the standard of living and wellbeing of some inhabitants of a society. Buildings create a platform through which most activities that aid development are executed; therefore, the significance of buildings in every nation of the world cannot be denied. However, although the building has been a blessing to some environments, it has not been in others. The production process and the planning of buildings on land have been issues due to the prevalence of abuses that are evident within our environment. Built environment abuse in Nigeria is highly evident in the increasing rate of structural failure, massive infernos due to limited spacing between buildings, and flooding due to the development of structures on drainage paths, among others. It was affirmed by Dauda, Abdulazeez and Abubakar (2012) that built environment abuse in Nigeria is second-to-none as human activities in the environment are carried out in a disorderly manner. A development that cannot guarantee safety, health and increases in the living conditions of the current and future generation is not a worthy development. Therefore, it is crucial that legislation is enacted that addresses the excesses observed within the built environment. According to Snelling (1997), building regulations are designed to ensure and guarantee the health, safety and convenience of people in or around the building. Meacham (2010) further affirmed that "building regulations are instruments that established rules of conduct, intended to ensure that buildings are constructed and operated in consonance with regulations, and provided standardised performance with respect to the building and safety of its occupants and the environment in which the building is situated." Building regulations ensure that the built environment is adequately preserved by dealing with scrupulous practices within the ambit of the law.

However, building regulations are not enough to create the built environment that we desire, and the need for enforcement of regulations has been an issue in every sphere of our nation. To address this need, the Lagos state Government signed a law establishing a building control agency on the 5 July 2010, to instil the order back into the built environment. Before the introduction of the building control agency, the only existing body comprised community health workers, who oversaw the health affairs of residential buildings in the state. The complexity of the state with respect to population growth and high building construction activities over time had outgrown the efficiency of the state health workers. The gap created due to the lack of a building control agency in the past led to the alarming rate of building collapse in the present. Windapo and Rotimi (2012) carried out a survey on building collapse across all states in Nigeria between 1974 and 2010. It is interesting to note that $51 \%$ of the instances of collapsed building were predominantly in Lagos. Udoma (2014) also cited in his report that between 2007 and 2012 there were 130 instances of building collapse in Lagos. He went further and said that more than 135 instances of building collapse were reported in 2013 alone in Lagos state. Negligence of the state in controlling development activities in the past has culminated in the present rate of building collapse. The Lagos State Building Control Agency (2011), however, affirmed that the embarrassing rate of building collapse within the state led to its creation to prevent the continuous and future occurrence of building collapse. 
The function of the agency is focused on ensuring the adherence to regulations by upholding established laws within the built environment. The rule of law has been an issue in our country, as it is evident how individuals and corporate bodies, among others, negate what has been established by the law. These acts of impunity have found their way into the built environment, and it is negatively impacting the environment. The prevalence of some practices that are not in accordance with international standards or building regulations has been increasing due to the lack of enforcement of building regulations. Additionally, Osinbajo (2004) identified non-enforcement of relevant laws as the major problem confronting our environment. To triumph over issues relating to the enforcement of certified laws within the built environment, it is therefore necessary to use a tool to monitor the effectiveness of the enforcement of building regulations. Reports from Building Control Performance Standards (2006) indicated building control as a tool used in achieving the objectives of building regulations. Similarly, Low (2011) opined that building control is an indispensable tool that defines the minimum standards that must govern the operation of the stakeholders in the built environment in consonance with existing laws. Building control is highly encompassing, as it ensures that the three phases of construction, including design, construction and handing over, are verified to be within the sphere of established regulations (Pedro et al., 2009). Building control is more concerned with enforcement of regulations within the built environment. Compliance with building regulations does not depend solely on the stakeholders due to those who break the law. As such, the enforcement of the use of building control tools results in synergy that can help achieve the built environment we desire.

Building control has a large role to play in the development and sustainability of the infrastructure of the built environment. Building control is thorough and flexible, as it dictates the structural soundness of the building during construction and the occupational health and safety of people involved in the building process (Low, 2011). Control and sustainability are two inseparable words in that the former preserves the latter. The relevance of building control in the built environment cannot be denied, as it ensures a view of the proposed state of the environment. It guarantees an ideal environment in which orderliness and sustainability are primary factors in any development. Like any other tool that has a definite procedure of use, the building control tool is not an exemption. Building Control Performance Standards (2006) reveal the processes of carrying out building control activities, and they include assessment of planning, site inspection, and issuance of a certificate of completion. In following these procedures, each stage is further supported. At the level of plan assessment, it is revealed that effective and continuing control of building works can be guaranteed at the design stage by ensuring certification of the following: intended use of the building, floor area, cubic capacity, number of stories, consideration of fire precautions, and accepted floor loading. Compliance with building regulations is ensured, and modification due to non-compliance is established. The Department for Communities and Local Government (2012) further affirmed the need for using legal tools in righting non-compliant work. Control of building works at the plan assessment stage is vital, as it dictates the success of the building control processes. Neglecting planning assessment will amount to an uncontrolled situation at the subsequent stage of construction; the impact of such negligence may be disastrous.

44/PENERBIT UNIVERSITI SAINS MALAYSIA 
The site inspection stage takes into full account the following; the degree of detail in the design assessment process, the experience of the builder, the nature of the work and statutory arrangements. The inspection stage is the most vital stage in the building control process, as it amounts to over $65 \%$ of the entire procedure of the building control system. Without a doubt, it is the stage at which building control tools play a pivotal role in ensuring safety, health and sustainability of our constructed environment. The smallest of the building control procedures addressed is the issuance of a certificate of occupancy. This stage affirms the fitness of the structure for habitation; it marks a milestone in the building control procedure.

Moreover, irrespective of the potential for lying in building control practices, it is surprising to discover that there are factors that still inhibit its beneficial role in the built environment. The findings of the Building Standards Division (2010) reveal that the low experience level of the personnel and lack of knowledge among building control personnel are the dominant factors affecting building control practices. Without a doubt, building control personnel must increase their knowledge in their area of specialisation because of the complexities of operations that revolve around buildings during the construction and post-construction stages. Knowledge gaps among building control personnel can affect the efficiency of the building control practice. Finally, Simon, Samuel and Edu (2015) identify corruption and the bureaucratic process as factors that cause the gap between building regulations and their enforcement. Corruption has been a pandemic that has ravaged every sphere of our society; its significance as a prominent factor affecting building control practices does not come as a surprise. The bureaucracy in the process of building control practices is another factor that must change; the process must be simplified if we are to have the expected order in our built environment.

\section{RESEARCH METHODOLOGY}

The aim of this study was to assess the effectiveness of building control tools with a focus on addressing the gap between existing building regulations and their enforcement in Lagos state. In attempting to achieve this objective, data were sourced from both primary and secondary sources. Primary data were collected with the aid of structured questionnaires administered to built environment professionals in selected contracting firms; they included architects, quantity surveyors, builders, civil engineers, electrical engineers and urban and regional planners. The sample was selected using the purposive sampling technique, a non-probabilistic technique. The tool was used to elicit controlled response. The professionals' views were sorted by their proximity to and involvement with building control processes. A total of 80 questionnaires were distributed among the professionals at contracting firms in Lagos, and 61 were returned. They were scrutinised for errors, omissions, completeness and inconsistencies and were found to be adequately completed. The calculated response rate was $76 \%$, indicating a good response rate.

The questionnaire was divided into three sections: section one examined the characteristics of the respondents, and the second section addressed the frequency of the enforcement of building control measures. The choices were on 
a Likert scale of 1-5 and were scored accordingly. Respondents were to give a score in accordance with the level of frequency, where $1=$ Never, $2=$ Rarely, $3=$ Sometimes, 4 = Often, 5 = Very often. The third section addressed the factors affecting the implementation of building control practices. The respondents were to attest to the degree of the effects of the factors in the following order on the Likert scale: 1 = Very low, $2=$ Low, $3=$ Moderate, $4=$ High, $5=$ Very high.

Descriptive statistics were used to analyse the respondents' characteristics. Mean item score was used to analyse the frequency of the building control measures and the factors affecting their implementation. The hypothesis was analysed with ANOVA, and the confidence level was set at $5 \%$.

\section{ANALYSIS AND RESULTS}

\section{Characteristics of Respondents}

In this section, the personal information of the respondents used for the study was analysed using percentages. The results obtained are presented in Table 1.

Table 1 shows the summary of the demographic characteristics of the respondents. The age bracket 21-31 years represents $45.9 \%$ of the total respondents. A total of $25 \%$ of the respondents are older than 31 years old. Less than $30 \%$ of the respondents fall within the other age brackets. The age bracket of over 50 years is the smallest, followed by the age bracket of respondents younger than 20 years old. The result shows the maturity of the respondents in terms of age.

It was also revealed that more than $60 \%$ of the respondents have a BSC/BTech as their academic qualification. Additionally, $29.5 \%$ of the respondents have an MSC/MBA, and $8.1 \%$ have higher national diploma (HND) as their highest academic qualification. Respondents with a PhD as their highest academic qualification represented the smallest percentage. The aggregate of the respondents' academic qualifications offer quality responses to the study.

It is observed from the findings that $36.1 \%$ of the respondents were professional builders, followed by surveyors and civil engineers, who each had a respondent rate of $16.4 \%$.

Table 2 shows that graduate and corporate members are well represented in the study. Among graduate groups, the NIOB has the highest percentage at $36.5 \%$, and it has the highest number of respondents. The NIOB was followed by the NSE at $28.8 \%$. Among the corporate groups, the NIOB and NSE are the highest, and they are tied at $35.7 \%$. It is evident that at the corporate level, both the NIOB and NSE are well rooted. The second highest in the corporate group is the NIQS, with $14.3 \%$. After critical review of the respondents' professions, it is evident that the knowledge base is good for the study. 
Table 1. Descriptive Characteristics of Respondents

\begin{tabular}{|c|c|c|}
\hline Characteristics & Frequency & Percentage \\
\hline \multicolumn{3}{|l|}{ Age } \\
\hline$<20$ years & 28 & 45.9 \\
\hline $31-40$ years & 27 & 44.3 \\
\hline $41-50$ years & 4 & 6.6 \\
\hline $51-60$ years & 2 & 3.3 \\
\hline Total & 61 & 100 \\
\hline \multicolumn{3}{|l|}{ Academic Qualification } \\
\hline HND & 5 & 8.1 \\
\hline $\begin{array}{l}\text { Bachelor of Science (BSC)/ } \\
\text { Bachelor of Technology } \\
\text { (BTech) }\end{array}$ & 37 & 60.7 \\
\hline $\begin{array}{l}\text { Master of Science (MSc)/ } \\
\text { Master of Business } \\
\text { Administration (MBA) }\end{array}$ & 18 & 29.5 \\
\hline Doctor of Philosophy (PhD) & 1 & 1.6 \\
\hline Total & 61 & 100 \\
\hline \multicolumn{3}{|l|}{ Profession } \\
\hline Architect & 5 & 8.1 \\
\hline Quantity surveyor & 10 & 16.4 \\
\hline Builder & 22 & 36.1 \\
\hline Civil engineer & 10 & 16.4 \\
\hline Urban and regional planner & 1 & 1.6 \\
\hline Electrical engineer & 6 & 9.8 \\
\hline Other & 7 & 11.5 \\
\hline Total & 61 & 100 \\
\hline
\end{tabular}

Table 2. Professional Affiliation and Grade of Membership

\begin{tabular}{lcccc}
\hline Membership Status & $\begin{array}{c}\text { Graduate } \\
\text { Frequency }\end{array}$ & Percentage & $\begin{array}{c}\text { Corporate } \\
\text { Frequency }\end{array}$ & Percentage \\
\hline $\begin{array}{l}\text { Nigerian Institute of } \\
\text { Architects (NIA) }\end{array}$ & 3 & 5.8 & 1 & 7.1 \\
$\begin{array}{l}\text { Nigerian Society of } \\
\text { Engineers (NSE) }\end{array}$ & 15 & 28.8 & 5 & 35.7 \\
$\begin{array}{l}\text { Nigerian Institute of Building } \\
\text { (NIOB) }\end{array}$ & 19 & 36.5 & 5 & 35.7 \\
$\begin{array}{l}\text { Nigerian Institute of Quantity } \\
\text { Surveyors (NIQS) } \\
\text { Others }\end{array}$ & 10 & 19.2 & 2 & 14.3 \\
\hline Total & 5 & 9.6 & 1 & 7.1 \\
\hline
\end{tabular}




\section{Enforcement of Building Tools}

This section reveals the varying measures of building control enforcements tools. These measures are identified and ranked as presented in Table 3.

From Table 3, the frequency of enforcement of building control measures occurs in the following order: Processing and scrutinising of building plans for approval is the measure that is most often observed for enforcement of building control, with a mean score of 4.05. This demonstrates that most building plans were approved prior to commencement of construction. This was followed by the inspection of construction work in progress, with a mean score of 3.49. The inspection of buildings completed according to the approved building plan for the issuance of certificates of occupancy had a mean score of 3.32. This is an indication that building inspection is one of the core measures needed for the control of building works. Taking action on unauthorised, dangerous and other contraventions of statutory requirements related to building was among the top four, with a mean score of 3.07. This signifies zero tolerance for the negligence of statutory requirements and dangerous structures that are a threat to human safety and health. The keeping of records in relation to building and related approvals, building control agency coordination with other statutory bodies to meet requirements and the establishment of a legal framework for immediate and continuous audits and certifications of existing building are the three lowest ranked, with mean scores of $3.00,2.87$ and 2.51 , respectively.

Table 3. Assessment of the Effectiveness of Building Control Measures

\begin{tabular}{|c|c|c|}
\hline Building Control Measure & Mean & Rank \\
\hline The processing and scrutinising of building plans for approval. & 4.05 & 1 \\
\hline The inspection of construction work in progress. & 3.49 & 2 \\
\hline $\begin{array}{l}\text { The inspection of the building completed according to approved } \\
\text { building plans for the issuance of certificates of occupancy. }\end{array}$ & 3.32 & 3 \\
\hline $\begin{array}{l}\text { The taking of action on unauthorised, dangerous work and on } \\
\text { contraventions of statutory requirements related to building. }\end{array}$ & 3.07 & 4 \\
\hline The keeping of records in relation to building and related approvals. & 3.00 & 5 \\
\hline $\begin{array}{l}\text { The co-ordination with other statutory bodies to meet requirements } \\
\text { e.g., roads, fire safety, environmental requirements, etc. }\end{array}$ & 2.87 & 6 \\
\hline $\begin{array}{l}\text { Establishing a legal framework for immediate and continuous audits } \\
\text { and certifications of existing buildings. }\end{array}$ & 2.51 & 7 \\
\hline
\end{tabular}

\section{Factors Affecting Building Control Practices}

This study identifies the various factors impacting building control practices, and they are ranked according to their order of significance in Table 4.

Table 4 reveals the varying factors affecting building control practices. Among these factors, corruption and bureaucratic process ranked high, with mean scores of 4.65 and 4.40 , respectively. This response indicates that corruption and the bureaucratic process strongly affect building control practices. Despite the presence of the building control tool, the reports garnered from our built environment are not encouraging due to limitation of the tools, which is caused by 
varying factors. Lack of coordination among agencies, as well as greed, are other striking factors affecting building control practices, with mean scores of 4.10 and 4.05, respectively. An inadequate legal framework for building control and a lack of enforcement mechanisms ranked 5th and 6th, with mean scores of 3.85 and 3.75, respectively, which signifies weak tools of authority. Lack of training, inadequate number of building control specialists and lack of personnel, with mean scores of $3.50,3.45$ and 3.30 , respectively, ranked at the bottom of the table. Such findings reveal that the effectiveness of the building control agency is dependent upon the availability of people with technical capacity. It is, however, surprising to discover that inadequate funding for agencies is the smallest factor acting against building control effectiveness, with a mean score of 2.80 .

Table 4. Factors Affecting Building Control Practices

\begin{tabular}{lcc}
\hline Factor & Mean & Rank \\
\hline Corruption & 4.65 & 1 \\
Bureaucratic process & 4.40 & 2 \\
Lack of coordination among agencies & 4.10 & 3 \\
Greed & 4.05 & 4 \\
Inadequate legal framework for building control & 3.85 & 5 \\
Lack of enforcement mechanisms & 3.75 & 6 \\
Lack of training & 3.50 & 7 \\
Inadequate number of building control specialists & 3.45 & 8 \\
Lack of personnel & 3.30 & 9 \\
Inadequate funding for agencies & 2.80 & 10 \\
\hline
\end{tabular}

\section{Research Hypothesis}

The hypothesis postulated for this study is that there are no significant differences among the groups of professionals regarding their perceptions of building control measures. The results garnered from the groups of professionals respondents are presented in Table 5.

The perceptions of the professional groups, including the builders, quantity surveyors, engineers and architects on the effectiveness of building control measures was tested, and the results are presented in Table 5. The level of statistical significance has been set to $5 \%$. Table 5 reveals that the $p$-values of all the processes of building control are above 0.05, which signifies no differences among the builders, quantity surveyors, engineers, architects and urban and regional planners on their perceptions. As such, the alternative hypothesis is rejected and the null hypothesis, which states that there is no significant difference among the professionals on their perceptions of the effectiveness of building control measures, is accepted. 
Table 5. ANOVA Results for Significant Level of Professional Opinion on Effectiveness of Building Control Measure

\begin{tabular}{|c|c|c|c|c|c|c|}
\hline & & $\begin{array}{l}\text { Sum of } \\
\text { Squares }\end{array}$ & df & $\begin{array}{l}\text { Mean } \\
\text { Square }\end{array}$ & $\boldsymbol{F}$ & $\begin{array}{l}p- \\
\text { value }\end{array}$ \\
\hline \multirow{3}{*}{$\begin{array}{l}\text { The process of scrutinising } \\
\text { building plans for approval. }\end{array}$} & Between groups & 3.659 & 6 & .610 & .836 & .548 \\
\hline & Within groups & 37.186 & 51 & .729 & & \\
\hline & Total & 40.845 & 57 & & & \\
\hline \multirow{3}{*}{$\begin{array}{l}\text { The inspection of } \\
\text { construction work in } \\
\text { progress. }\end{array}$} & Between groups & 6.692 & 6 & 1.115 & .905 & .498 \\
\hline & Within groups & 64.054 & 52 & 1.232 & & \\
\hline & Total & 70.746 & 58 & & & \\
\hline \multirow{3}{*}{$\begin{array}{l}\text { The inspection of buildings } \\
\text { completed according to } \\
\text { approved building plans for } \\
\text { the issuance of certificates } \\
\text { of occupancy. }\end{array}$} & Between groups & 5.789 & 6 & .965 & .965 & .458 \\
\hline & Within groups & 50.987 & 51 & 1.000 & & \\
\hline & Total & 56.776 & 57 & & & \\
\hline \multirow{3}{*}{$\begin{array}{l}\text { The taking of action on } \\
\text { unauthorised, dangerous } \\
\text { work and on } \\
\text { contraventions of statutory } \\
\text { requirements related to } \\
\text { building. }\end{array}$} & Between groups & 5.471 & 6 & .912 & .886 & .512 \\
\hline & Within groups & 53.512 & 52 & 1.029 & & \\
\hline & Total & 58.983 & 58 & & & \\
\hline \multirow{3}{*}{$\begin{array}{l}\text { The keeping of records in } \\
\text { relation to building and } \\
\text { related approval. }\end{array}$} & Between groups & 9.245 & 6 & 1.541 & 1.233 & .305 \\
\hline & Within groups & 63.738 & 51 & 1.250 & & \\
\hline & Total & 72.983 & 57 & & & \\
\hline \multirow{3}{*}{$\begin{array}{l}\text { The co-ordination with } \\
\text { other statutory bodies to } \\
\text { meet their requirements } \\
\text { e.g., roads, fire safety, } \\
\text { environmental } \\
\text { requirements, etc. }\end{array}$} & Between groups & 8.152 & 6 & 1.359 & 1.392 & .236 \\
\hline & Within groups & 50.763 & 52 & .976 & & \\
\hline & Total & 58.915 & 58 & & & \\
\hline \multirow{3}{*}{$\begin{array}{l}\text { Establishing a legal } \\
\text { framework for immediate } \\
\text { and continuous audit and } \\
\text { certification of existing } \\
\text { buildings. }\end{array}$} & Between groups & 11.129 & 6 & 1.855 & 1.213 & .315 \\
\hline & Within groups & 79.515 & 52 & 1.529 & & \\
\hline & Total & 90.644 & 58 & & & \\
\hline
\end{tabular}

\section{DISCUSSION OF FINDINGS}

This study indicated that the state of building control practices in Lagos state is very porous. It was evident from the study that most of the measures of building control are not followed to the letter of the law. Among the building control measures, it was only "processing and scrutinising of building plans for approval" that was thoroughly observed according to the study. Every other measure that was equally important was not monitored thoroughly. Based on the findings, inspection of ongoing construction site work was not carried out adequately by building control agencies; this can result in the sub-standard execution of 
construction. Negligence in upholding such relevant measures was among the reasons why the alarming rate of building collapse is increasing within the state. In the same vein, the study revealed that thorough action was not taken on unauthorised or dangerous work and other contraventions of statutory requirement in the building. Buildings were constructed against statutory requirements. Dangerous buildings are a threat to human health and safety, and the inability of the agencies to strongly uphold such measures will amount to environmental catastrophe, which is possible in our state today. The study also revealed the various factors confronting building control practices, such as corruption and the bureaucratic process, which ranked high in the study. The emergence of corruption as the highest ranked among other factors is not surprising due to the present state of the country. According to the corruption perception index, Nigeria was ranked 136th out of 176 countries in 2014. It was evident that there is a correlation between corruption at the macro and the micro level. To set every sector of the country back on the right track, corruption must be confronted early on. The bureaucratic process is another striking factor challenging building control practices and is due to the insensitivity of the agency to the environment. As revealed in the study, lack of coordination and greed also stand as threats to the capacity of the building control agency. An inadequate legal framework for building control and the lack of enforcement mechanisms are other striking factors that inhibit the performance of the building control agency. Such findings reveal how vulnerable our building control system has been due to a lack of legal tools and enforcement mechanisms. The study also revealed that lack of training, inadequate of building control specialists and lack of personnel, among others, are urgent issues that must be given attention. The built environment is an industry whose technical and skill requirements are very high. In the same vein, building control agents' technical and skilful capacity should not be lacking so that they can perform as required. Inadequate funding for the agency is the lowest-ranked factor. Nevertheless, it is highly instrumental in the success of the function of the agency. Hypothesis testing revealed that there is no significant difference among the professionals (architects, builders, engineers, urban and regional planners and quantity surveyors) on their perceptions of building control practices in Lagos state.

\section{CONCLUSIONS AND RECOMMENDATION}

From the study conducted, it is evident that the sustainability of the built environment is dependent on the effectiveness of the building control tool. It is revealing to know that aside from the process of scrutinising building plans for approval measures, which ranked highest, most of the measures of building control received scores of approximately three in the frequency range, which signifies "sometimes" on the Likert scale.

The inspection of building works in progress, which cannot be denied as one of the relevant measures within the range of specified measures of building control tools, was on a medium scale. The findings negate the perception of the Building Control Performance Standard (2006), which cited that for there to be effective building control process, thorough and frequent site inspection should not be compromised. 
Another significant measure that was not given a high priority in the findings is "the taking of action on unauthorised, dangerous work and on contraventions of statutory requirements related to building", as it ranked below the expected range. To attain a healthy, safe and sustainable built environment, adherence to the building control measures should be the highest priority.

The study also revealed the varying factors competing within the implementation of building control practices. It is not surprising to know that corruption is the most striking factor affecting building control practices. Corruption is a pandemic that can be identified with our society, as it cuts across every sphere of our nation. As the saying in our nation states, "if we do not kill corruption, corruption will kill us". Without a doubt, the second line of the statement is what is possible in our environment today. The alarming rates of reports on negative events such as building collapses, massive flooding, and building fires are major products of corruption.

The bureaucratic process was also ranked highly among the factors affecting building control. This is impacting negatively on the environment because many people are discouraged from preparing a proper application prior to starting construction work. The negligence of individuals and bodies to make their intentions known to the statutory body contributed to the ugly occurrences experienced in our built environment.

In short, the study revealed weaknesses in the enforcement of existing regulations in our built environment; adherence to most building control measures is weak. The gap that exists between building regulations and their enforcement is evident with the reality that is still prevalent in our built environment, such as the high rates of building collapse, building fires, and environmental destruction.

From the study, the following recommendations are made to improve the gap that exists between building regulations and their enforcement in Lagos state.

1. There should be regular auditing of the performance of the building control agency to ensure that standards have not been compromised and to put authority in check due to the prevalence of corruption.

2. Government should intensify in its fight against corruption. If corruption can be confronted early, most sectors of the economy will be corrected, including the built environment.

3. The process of building control practices should be simplified, and its objectives should not be compromised.

4. The legal framework and its implementation should be the first priority in building control practices.

5. The availability of skilled personnel should be ensured in building control practice.

6. Funding of agencies should be given high priority, as they help to achieve the other recommendations.

7. Coordination among agencies should be encouraged, as this will help mitigate the inadequacy of personnel and otherwise. 


\section{REFERENCES}

Alexander, K. (2011). Building control and performance: As if people and the planet matter. Procedia Engineering, 20: 1-11. https://doi.org/10.1016/j. proeng.2011.11.134.

Building Standards Division (2010). Improving Compliance with Building Regulation. Edinburgh: Directorate for Built Environment, Scottish Government.

Dauda, D., Abdulazeez, A.D. and Abubakar, M.A. (2010). An evaluation of the adequacy of the national building code for achieving sustainable built environment in Nigeria. Research Journal of Environmental and Earth Science, 4(10): 857-865.

Department for Communities and Local Government (2006). Building Control Performance Standards. London: Eland House.

Department for Communities and Local Government (2012). Risk Assessment Decision Making Tools for Building Control Bodies. London: Eland House.

Filani, M.O. (2012). The Changing Face of Lagos from Vision to Reform and Transformation. Ibadan, Nigeria: Cities Alliance. Available at: http://www.citiesalliance.org/sites/citiesalliance.org/files/Lagos-reformreport-lowres.pdf.

Hossein, Z., Farah, H. and Leila, M. (2012). Sustainability in building construction: Revising definitions and concepts. International Journal of Emergency Sciences, 2(4): 570-578.

Low, S.P. (2011). Building and sustainability control in Singapore: A journey in time. Procedia Engineering, 20: 22-24. https://doi.org/10.1016/j.proeng.2011. 11.136.

Meacham, B.J. (2010). Performance-Based Building Regulatory Systems: Principle and Experiences. New Zealand: Inter-jurisdiction Regulatory Collaboration Committee.

Osinbajo, O.Y. (2004). Problem and prospect of developments control. Paper presented at the 2004 Annual Delegates Conference of the Nigerian Bar Association Holding. International Conference Centre, Abuja, 22-27 August 2004.

Pedro, J.B., Meijer, F. and Visscher, H. (2009). Comparison of task and responsibilities in the building control system of European Union countries. RICS COBRA Research Conference. University of Cape Town, Cape Town, 10-11 September. Cape Town: Royal Institution of Chartered Surveyors (RICS), 1339-1355.

Simon, O.A., Samuel, K.A. and Edu-Buandoh, K.B.M. (2015). Assessment of factors affecting implementation of the national building regulations (L.I.1630) in Ghana. Journal of Public Policy and Administration Research, 5(2): 1-10.

Snelling N. (1997). Home Ownership-Buying and Selling. East Sussex, UK: Guild of Master Craftsmen Publication Ltd., 159-170.

Udoma, O.U. (2014). Why are So Many Buildings Collapsing in Lagos?. Philadelphia, PA: Next City. Available at: https://nextcity.org/daily/entry/why-are-somany-buildings-collapsing-in-lagos [Accessed on 10 January 2016].

Van der Heijden, J. and De Jong, J. (2013). Towards a better understanding of building regulation. Environment and Planning B, 36(6): 1038-1052. https://doi.org/10.2139/ssrn.2204177. 
R.A. Ojelabi, O.O. Oyeyipo and A. Afolabi

Windapo, A.P. and Rotimi, J.O. (2012). Contemporary issues in building collapse and its implication for sustainable developments. Buildings, 2(3): 283-299. https://doi.org/10.3390/buildings2030283. 